\title{
Executives' Overconfidence, Political Connection and Acquisition Premium of Enterprises
}

\author{
Nian Liu, Weihong Chen \\ School of Business Administration, South China University of Technology, Guangzhou, China \\ Email: 1076408362@qq.com
}

How to cite this paper: Liu, N. and Chen, W.H. (2017) Executives' Overconfidence, Political Connection and Acquisition Premium of Enterprises. Journal of Service Science and Management, 10, 260-279. https://doi.org/10.4236/jssm.2017.103022

Received: May 21, 2017

Accepted: June 10, 2017

Published: June 13, 2017

Copyright $\odot 2017$ by authors and Scientific Research Publishing Inc. This work is licensed under the Creative Commons Attribution International License (CC BY 4.0).

http://creativecommons.org/licenses/by/4.0/ (c) (i) Open Access

\begin{abstract}
Based on the behavioral finance, the study explores the relationship and mechanism among the political connection, executives' overconfidence and acquisition premium in the specific institutional context of China's transitional economy. The empirical study of the acquisition events of all A-share listed companies from 2007 to 2014 shows that the psychological bias of the executives' overconfidence has significantly enhanced the size of premium paid for the acquisitions after controlling for four other factors that may affect the acquisition premium; The political connection will weaken the influence of executives' overconfidence on the acquisition premium; However, political connection level is not necessarily an important safeguard against weakening the impacts of the executives' overconfidence. The results show that enterprises with overconfident executives need to correctly examine the advantages and disadvantages in the process of political connection construction, further improve the corporate governance mechanism, and use benign political connections to help overconfident managers make scientific and reasonable investment decisions, and finally help enterprises to realize healthy development.
\end{abstract}

\section{Keywords}

Behavioral Finance, Executives' Overconfidence, Acquisition Premium, Political Connection, Political Connection Level

\section{Introduction}

With the continuous improvement of the degree of opening up, Chinese enterprises are facing more and more turbulent market competition environment. To enhance their competitiveness, acquisitions have become the most preferred 
strategic choice for Chinese enterprises. However, the frequent acquisitions are accompanied by serious premium phenomenon. Throughout the domestic and international acquisition premium behavior of enterprises, we find the majority of enterprises fell into a financial crisis, and gradually went to a loss or even bankruptcy due to paying too high premium. Nevertheless, enterprises are still on the way. This phenomenon has aroused wide concern among the scholars and gradually become an important research topic.

Foreign scholar Roll (1986) proposes "overconfidence hypothesis" to give a scientific explanation. He believes that even in the case that acquisitions are paid significantly higher than the market price or seriously damaged the value of the enterprises, overconfident executives still often initiate acquisition activities [1], Which spreads the research on the relationship between executives' overconfidence and acquisition decision-making based on behavioral finance at home and abroad [2]. Malmendier \& Tate (2003) find that overconfident executives are more likely to conduct "low-quality" acquisitions of value destruction [3]. Song and Dai (2015) empirically test overconfident managers can significantly reduce the company's financial performance and market performance after acquisitions [4]. Therefore, the study of factors strengthening or weakening the adverse impacts of executives' overconfidence on the enterprise decisions of acquisition has substantial practical and theoretical significance.

Existing research on the factors strengthening or weakening the adverse impacts of executives' overconfidence on the enterprise decisions of acquisition suggest they are mainly conducted from the perspective of the governance structure of the board and the capital structure. For example, Hayward \& Hambrick (1997) find the separation between CEO and chairman of the board or higher proportion of independent directors, will weaken the impact of CEO hubris on the premiums [5]. Zhu and $\mathrm{Yu}$ (2015) also find that the separation between the chairman and the CEO, the increase in the number of board meetings may undermine the positive correlation between executives' overconfidence and acquisition activities [6]. Malmendier \& Tate (2006), Zhai and Zhang(2012) have found that overconfident executives have high cash flow sensitivity and are prone to over-investments when companies have sufficient cash flow [7] [8].

It is showed that enterprises can obtain massive resource benefits by establishing political connection in the specific institutional context of China's transitional economy [9], such as preferential financing and investment treatment [10]; more government subsidies and more favorable tax rates [11]; regulatory easing, easier to break industry barriers; as an alternative mechanism for property rights protection, offset some of the negative effects of the institutional environment [11]; make full use of government monopoly resources [9], etc. However there are obvious inconsistencies in the conclusions about effects of political connection on enterprises' strategic decisions and performance. We hold that these studies are mainly "capital" perspective in the backgroud that executives are completely rational, while ignoring the factor of executives' irrationality and the influences of other mechanisms of political connection, such as 
weakening illusion control and providing information. Therefore, combining executives' irrationality with political connection and considering these two mechanisms, we study the role of political connection in strengthening or weakening the adverse impacts of executives' overconfidence on the enterprise decisions of acquisition.

This paper breaks through the existing research based on the perspective of capital and board of directors, and studies the mechanisms of weakening or strengthening the influence of overconfidence on the acquisition premium from the perspective of political connection, which is conductive to reveal a deep-level mechanisms about how the political connection affect the enterprise strategic decision-making and selection, also help enterprises to further consider how to improve their governance mechanism to help managers make scientific and rational investment decisions, and finally help enterprises to realize healthy development.

\section{Theory and Hypothesis}

\subsection{Executives' Overconfidence and Acquisition Premium}

Behavioral finance is a cognitive psychology research on People's behavior and decisions under the uncertain conditions. Based on the upper echelon theory and behavioral decision theory, it further studies the influence of all kinds of psychological characteristics of managers on enterprise's investment decision (such as overconfidence) under the conditions of environmental uncertainty, incomplete information and limited individual ability. Behavioral finance combines irrational factors with business activities, providing a new perspective to explain frequently occurred acquisition anomalies in the market. In this study, on the basis of behavioral finance executives' overconfidence shows five psychological activities:

First, overestimating their ability. Overconfident executives think they have a wealth of knowledge and experience to overestimate their ability to predict and judge, the ability to discover new information, the ability to manage and the ability to complete the task, that they can do more difficult projects [12]. Second, overestimating the possibility of project success. Overconfident executives tend to overestimate investment returns and underestimate investment risk, underestimate the benchmark rate of failure to enter emerging markets [13], underestimate the cultural conflicts that arise from acquisitions, and so on, and thus they have a blind optimism about the success of the project. Third, underestimating the uncertainty of the environment. Overconfident executives believe that behavior and outcome are determined by the factors in control rather than the factors out of control. The greater their awareness of control, the greater the likelihood of underestimating uncertainty and risk, the greater tendency to make risky decisions [12]. They desire to demonstrate their ability through the successful implementation of acquisition decisions. Fourth, overestimating arising synergies from acquisitions. Weston's synergistic theory includes operational, managerial, and financial synergies. Operational synergies can bring economies 
of scale and economies of scope; management synergies can make the acquirers and the targets to learn from each other; financial synergies can enable enterprises to obtain internal and external financing with a smaller cost. Overestimation of synergies can also lead to overconfident executives with higher acquisition tendencies. Last, overestimating the ability of the target business to create profits [3]. Overconfident executives tend to overestimate the resource capabilities and prospects of the target firm, believing that they can create greater wealth for the firm after acquisitions.

In general, these five psychological activities have significantly influenced overconfident executives' perception of acquisition activities, believing that they have the ability to take on more challenging acquisitions, can deal well with the difficulties and obstacles during the process of acquisitions, comfirming acquisitions can bring the benefits of synergy effect, to create greater wealth for themselves, which makes them willing to pay higher premiums for successful acquisitions. Therefore, we hypothesize:

Hypothesis 1: Executives' overconfidence is positively related to the premium paid for the acquisitions.

\subsection{Moderating Role of the Political Connection}

Under the background of deepening reform and accelerating economic transformation and upgrading, and that the system vacancy and institutional conflict has existed for a long time, the Chinese government still has strong intervention in the operation of enterprises. At the same time, burdened with the social pension, employment promotion, social security maintenance and stability and other multiple policy burden, for their own interests the government often use their own power to intervene in the enterprises' management activities, requiring enterprises to share the government's commitment and responsibilities to these policy [11] [14], which leads the government to produce a strong tendency to control the enterprises.

Studies shows that when people are able to decide on an investment project and have an absolute influence on the outcome of the projects, they will have a control illusion [15]. The illusion control will make overconfident managers choose more challenging projects, make more bold decisions. When enterprises establish political connection, especially in the way to establish that the executives currently or have served in the government, or as a member of the National People's Congress or CPPCC members, the government is strengthening intervention and control on the enterprise management decision. The existence of government intervention and control will not only reduces the control of decision-making of executives, but also make the business performance be more dependent on political connection, rather than the manager's own ability, resulting in the weakening of executive's control illusion, and thus make the overconfident executives appear cautious in making investment decisions to inhibit the corporate acquisition premium. The higher the level of political association, the higher the degree of government intervention and control, the stronger the de- 
pendence of the enterprise on the political connection, the stronger the control illusion is impaired, the easier the influence of the executives confidence on the acquisition premium is weakened.

In addition, corporate executives just interpret the limited state's macroeconomic policies, market information, and other corporate information. But by building political connection, they can gain a more comprehensive understanding and master more reliable information to help make rational investment decisions, avoiding irrational investment behavior. And in the current political and economic environment, the higher levels of government has a much more comprehensive understanding of macroeconomic policies, the market information on other companies than the lower government. Therefore, when enterprises' political connection are in higher level, there are more channels to obtain valued information and the information is more complete, more reliable, so that overconfident executives can be more cautious, objective and rational to make the appropriate acquisition decision-making, inhibit the level of corporate acquisition premium.

Both two mechanisms of political connection-weakening illusion control and providing information make overconfident executives become more cautious to making acquisition decisions, which to some extent inhibits the corporate acquisition premium. Therefore, we hypothesize:

Hypothesis 2a: The relationship between executives' overconfidence and acquisition premium will be negatively moderated by the political connection.

Hypothesis 2b: The higher the level of corporate political connection, the more likely to weaken the impact of executives' overconfidence on acquisitions premium.

\section{Methods}

\subsection{Data and Sample}

We utilize the acquisition events implemented by all A-share listed companies from 2007 to 2014 as the initial sample. All acquisition events are based on the sample company as the acquirers, not the targets. After excluding the samples of the financial companies, ST, ${ }^{\star} \mathrm{ST}$ companies, the samples of listed companies in the same year, the samples that CEOs are changed, the samples that do not disclose earnings forecasts and disclose the forecast information after the end of the disclosure period, and the samples of companies that implemented debt restructuring and tender offer, as well as the samples of missing values and outliers, our final sample consists of 419 observed values (see Appendix 1). The data came from th China Listed Firm's Merger \& Acquisition, Asset Restructuring Research Database in the CSMAR.

\subsection{Measures}

- Acquisition premiums. According to the unique China's capital market, this paper takes the measurement methods commonly used by domestic scholars

[16] [17]. Acquisition premiums are commonly defined as the acquirer' bid 
minus the targets' preannouncement market value divided by the targets' preannouncement market value. The higher the ratio, the Larger the size of acquisition premium.

- Executives overconfident (OC). At present, there are a variety of ways to measure executives' overconfidence, such as: 1) executives stock options or stock holdings [3] [7]; 2) business climate index [18]; 3) executives relative compensation [12]; 4) earnings forecast bias. Lin, $\mathrm{Hu}$, Chen (2005) first identified if the company's annual profit is more than the actual, the executives will be overconfident; Yu (2008) and Jiang (2009) etc. also consider the inconsistency between the performance forecasts and actual performance as a judge whether the executives are overconfident; 5) mainstream media evaluation [5]; 6) the frequency of acquisitions [19]; 7) executives personal characteristics [18]. The advantages and disadvantages of these seven kinds of measurement methods have been widely discussed. Considering the needs of empirical research, data availability and special circumstances of China's securities market, we mainly use two methods to measure and test the robustness by the second method.

- The first method is to learn from Yu, Jiang and others' approach, according to the listed company's annual performance notice to determine whether the executives are overconfident (OC1). The type of performance forecasts includes four optimistic expectations (slightly increased, deficit loss, continued surplus, pre-increase) and four pessimistic expectations (slightly reduced, the first loss, continued losses, reduction). We choose four optimistic expectations as a sample of the study, if the optimistic expectations don't come true (that is, the performance forecasts and the actual performance is inconsistent), the executives will be defined as overconfidence, the value is 1 , otherwise 0 .

- Learning from $\mathrm{Yu}, \mathrm{Li}, \mathrm{Pan}$ and others' approach, the second is to use composite index composed of individual indicators of executives personal characteristics as a measure of overconfidence. The personal characteristics of the executives include: 1 ) gender. Women are more conservative and cautious than men; 2) age. Younger executives are more likely to make risk decisions, and if the age of executive is less than the sample mean, the value is 1 , otherwise $0 ; 3$ ) education. People who receive high level of education firmly believe that their own ability and the accuracy of judgment, and behave more confident. If the degree is above the undergraduate, the value is 1 , otherwise 0 ; 4) educational background. Executives with administrative backgrounds have a deeper understanding of risk and are less likely to be overconfident. If the executive does not have an administrative background, the value is 1 , otherwise 0 ; ) the separation of positions. If $\mathrm{CEO}$ is the chairman of the board at the same time, it will become more confident, the value is 1 , otherwise 0 . Based on the total value of the above five features, a comprehensive index is constructed. If the composite index is 4 or 5 , it is defined as overconfidence (OC2), the value is 1 , otherwise 0 .

- Political connection (PC). Based on the particular domestic institutional en- 
vironment and the actual situation of Chinese enterprises, we examine the political connection from two dimensions: First, political connection. If the chairman, general manager or CFO of the company currently or have served in the government, or as a member of the National People's Congress or CPPCC members, that means the company has a political connection [20] [21], the value is 1 ,otherwise 0 . Second, political connection level (PCL). The corresponding assignment is $5,4,3,2,1$, according to the executive in the administrative level of the division of the work unit for the national, provincial, municipal, county level and below. The higher the score, the higher the level.

- Control variables. Following existing research, we control the 13 variables that may have an impact on the acquisition premium, which is divided into four categories. First, firm characteristics, acquirer firm size, age, cash flow and ROA. Second, Governance structure: the proportion of independent directors; ownership concentration. Third, acquisition characteristics: history, payment methods, financial advisor. Forth, other conventional influences: executives age, financial crisis, industry and year.

\subsection{Regression Model}

In order to test the relationship between executives' overconfidence and acquisition premium, we establish mode 1 .

$$
\begin{aligned}
P R_{i, t}= & \alpha_{0}+\alpha_{1} \text { OC }_{i, t}+\alpha_{2} \text { Size }_{i, t}+\alpha_{3} \text { Age- }_{i, t}+\alpha_{4} \text { Cash- }_{i, t}+\alpha_{5} \text { ROA }_{i, t} \\
& +\alpha_{6} \text { Ind-ratio }_{i, t}+\alpha_{7} \text { Share- }_{i, t}+\alpha_{8} \text { History }_{i, t}+\alpha_{9} \text { Method }_{i, t} \\
& +\alpha_{11} \text { Adviser }_{i, t}+\alpha_{12} \text { FCP }_{i, t}+\alpha_{13} \text { Industry }_{i, t}+\alpha_{14} \text { Year }_{i, t}+\varepsilon
\end{aligned}
$$

In order to further test the relationship between the political connection, the overconfidence of executives, and acquisition premium, we establish the following model 2 and model 3.

$$
\begin{aligned}
P R_{i, t}= & \alpha_{0}+\alpha_{1} O_{i, t}+\alpha_{2} P_{i, t}+\alpha_{3} O_{i, t} \times P C_{i, t}+\alpha_{4} \text { Size }_{i, t}+\alpha_{5} \text { Age- }_{i, t} \\
& +\alpha_{6} \text { Cash- }_{i, t}+\alpha_{7} \text { ROA }_{i, t}+\alpha_{8} \text { Ind-ratio }_{i, t}+\alpha_{9} \text { Share- }_{i, t}+\alpha_{10} \text { History }_{i, t} \\
& +\alpha_{11} \text { Method }_{i, t}+\alpha_{12} \text { Adviser }_{i, t}+\alpha_{13} F P_{i, t+} \alpha_{14} \text { Industry }_{i, t}+\alpha_{15} \text { Year }_{i, t}+\varepsilon \\
P R_{i, t}= & \alpha_{0}+\alpha_{1} O C_{i, t}+\alpha_{2} P C L_{i, t}+\alpha_{3} O_{i, t} \times P C L_{i, t}+\alpha_{4} \text { Size }_{i, t}+\alpha_{5} \text { Age- }_{i, t} \\
& +\alpha_{6} \text { Cash- }_{i, t}+\alpha_{7} \text { ROA }_{i, t}+\alpha_{8} \text { Ind-ratio }_{i, t}+\alpha_{9} \text { Share- }_{i, t}+\alpha_{10} \text { History }_{i, t} \\
& +\alpha_{11} \text { Method }_{i, t}+\alpha_{12} \text { Adviser }_{i, t}+\alpha_{13} \text { FCP }_{i, t}+\alpha_{14} \text { Industry }_{i, t}+\alpha_{15} \text { Year }_{i, t}+\varepsilon
\end{aligned}
$$

\section{Results}

\subsection{Regression Analysis}

We use the STATA/MP 13.1 for data analysis. Table 1 presents the means, standard deviations and correlations of the variables that we measure in the model. The average value of the acquisition premium is 0.064 and the standard deviation is 0.159 , which indicates that there is a significant difference in the size of acquisition premium of different enterprises. The mean value of the political connection is 0.456 , the standard deviation is 0.499 , the mean level of political 
Table 1. Descriptive statistics and correlation analysis.

\begin{tabular}{|c|c|c|c|c|c|c|c|c|}
\hline variable & mean & S.d & $P R$ & $\mathrm{OC} 1$ & PC & PCL & Size & Age_C \\
\hline PR & 0.063571 & 0.159179 & 1 & & & & & \\
\hline OC1 & 0.252983 & 0.435241 & 0.038 & 1 & & & & \\
\hline PC & 0.455847 & 0.498642 & -0.057 & 0.03 & 1 & & & \\
\hline PCL & 1.513126 & 1.853922 & -0.041 & -0.06 & $0.893^{* * *}$ & 1 & & \\
\hline Size & 21.855864 & 1.027296 & $-0.100^{\star \star}$ & -0.017 & 0.019 & 0.029 & 1 & \\
\hline Age_C & 1.756776 & 0.816632 & $-0.166^{* * *}$ & $0.192^{\star * *}$ & $-0.085^{\star}$ & $-0.140^{\star * *}$ & $0.350^{* * *}$ & 1 \\
\hline Cash_F & 3.903552 & 10.776593 & $-0.105^{\star *}$ & $-0.104^{\star *}$ & 0.026 & 0.037 & $0.616^{* * *}$ & $0.238^{\star * *}$ \\
\hline ROA & 0.083158 & 0.050135 & -0.025 & -0.021 & $0.168^{* * *}$ & $0.161^{\star * *}$ & 0.051 & 0.052 \\
\hline Ind_ratio & 0.332561 & 0.07121 & $0.085^{\star}$ & -0.043 & 0.048 & $0.133^{* * *}$ & 0.012 & 0.064 \\
\hline Share_F & 0.371028 & 0.151973 & $-0.108^{\star \star}$ & $-0.168^{\star * *}$ & $-0.147^{\star * *}$ & -0.059 & $0.217^{\star * *}$ & -0.041 \\
\hline History & 0.818616 & 0.385797 & 0.063 & 0.032 & $0.083^{*}$ & $0.104^{* *}$ & $0.237^{\star * *}$ & $0.186^{* * *}$ \\
\hline Method & 0.835322 & 0.371333 & $0.177^{\star * *}$ & 0.007 & $0.109^{\star *}$ & $0.199^{\star * *}$ & 0.055 & $-0.225^{\star * *}$ \\
\hline Advisor & 0.171838 & 0.37769 & $-0.169^{* * *}$ & -0.003 & -0.061 & $-0.136^{\star * *}$ & -0.001 & $0.202^{\star * *}$ \\
\hline Age_T & 47.140811 & 5.323212 & -0.009 & -0.048 & $0.088^{*}$ & $0.104^{\star \star}$ & -0.022 & 0.028 \\
\hline variable & Cash_F & ROA & Ind_ratio & Share_F & History & Method & Advisor & Age_T \\
\hline Cash_F & 1 & & & & & & & \\
\hline ROA & $0.114^{\star *}$ & 1 & & & & & & \\
\hline Ind_ratio & $-0.113^{\star *}$ & $0.176^{* * *}$ & 1 & & & & & \\
\hline Share_F & $0.160^{* * *}$ & -0.034 & $0.096^{*}$ & 1 & & & & \\
\hline History & $0.136^{\star * *}$ & 0.05 & -0.048 & 0.032 & 1 & & & \\
\hline Method & 0.039 & 0.034 & -0.006 & 0.05 & $0.108^{\star *}$ & 1 & & \\
\hline Advisor & -0.07 & -0.073 & -0.022 & $-0.106^{\star *}$ & -0.015 & $-0.736^{\star * *}$ & 1 & \\
\hline Age_T & 0.035 & 0.078 & 0.06 & $-0.165^{\star * *}$ & -0.027 & -0.069 & $0.091^{\star}$ & 1 \\
\hline
\end{tabular}

Note: ${ }^{* * *},{ }^{* *}$ respectively indicate significant correlation at $10 \%, 5 \%, 1 \%$ level. $\mathrm{T}$ values in brackets.

connection is 1.513 , the standard deviation is 1.854 , indicating that many enterprises are actively establishing the political connection, and there are great differences in the level of political connection of different enterprises. The correlation coefficient of political connection and political connection level is 0.893 . It is so high mainly because the political connection level is evaluated with political connections in the sample. In order to avoid serious mutual linear problem, the study will be on the two variable regression analysis respectively. In addition, the correlation degree of other variables is low. The correlation coefficient between overconfidence and premium is 0.038 , which is positive correlation but not significant. So we need to further test in regression analysis.

Acquisition premium is a continuous variable that can be analyzed by using a general linear model. Table 2 shows the results of using OC1 to measure executives' overconfidence. The models (1), (2), (3) show the regression results of the relationship between executives' overconfidence, political connection and acqui- 
Table 2. Relationship between overconfidence and acquisition premium test (OC1).

\begin{tabular}{|c|c|c|c|c|c|c|}
\hline variables & Model (1) & Model (2) & Model (3) & Model (4) & Model (5) & Model (6) \\
\hline \multirow[t]{2}{*}{$\mathrm{OC} 1$} & & $0.017^{\star *}$ & $0.017^{\star *}$ & & $0.016^{*}$ & $0.016^{*}$ \\
\hline & & $(2.22)$ & (2.19) & & (1.79) & $(1.75)$ \\
\hline \multirow[t]{2}{*}{$\mathrm{PC} \times \mathrm{OC} 1$} & & & $-0.034^{\star *}$ & & & \\
\hline & & & $(-1.98)$ & & & \\
\hline \multirow[t]{2}{*}{$\mathrm{PCL} \times \mathrm{OC} 1$} & & & & & & 0.002 \\
\hline & & & & & & $(0.42)$ \\
\hline \multirow[t]{2}{*}{ PC } & -0.034 & -0.035 & -0.035 & & & \\
\hline & $(-1.48)$ & $(-1.51)$ & $(-1.51)$ & & & \\
\hline \multirow[t]{2}{*}{ PCL } & & & & -0.010 & -0.010 & -0.010 \\
\hline & & & & $(-1.53)$ & $(-1.53)$ & $(-1.48)$ \\
\hline \multirow[t]{2}{*}{ Size } & -0.008 & -0.008 & -0.008 & -0.008 & -0.008 & -0.008 \\
\hline & $(-0.74)$ & $(-0.78)$ & $(-0.81)$ & $(-0.70)$ & $(-0.74)$ & $(-0.73)$ \\
\hline \multirow[t]{2}{*}{ Age_C } & $-0.031^{\star}$ & $-0.033^{*}$ & $-0.033^{*}$ & $-0.032^{\star}$ & $-0.034^{*}$ & $-0.034^{\star}$ \\
\hline & $(-1.79)$ & $(-1.93)$ & $(-1.94)$ & $(-1.78)$ & $(-1.91)$ & $(-1.89)$ \\
\hline \multirow[t]{2}{*}{ Cash_F } & -0.000 & -0.000 & -0.000 & -0.000 & -0.000 & -0.000 \\
\hline & $(-0.42)$ & $(-0.21)$ & $(-0.23)$ & $(-0.36)$ & $(-0.17)$ & $(-0.15)$ \\
\hline \multirow[t]{2}{*}{ ROA } & 0.127 & 0.140 & 0.131 & 0.134 & 0.144 & 0.150 \\
\hline & $(1.26)$ & $(1.34)$ & $(1.21)$ & (1.49) & $(1.57)$ & $(1.52)$ \\
\hline \multirow[t]{2}{*}{ Ind_ratio } & $0.267^{\star}$ & $0.271^{\star *}$ & $0.270^{\star \star}$ & $0.287^{\star *}$ & $0.291^{\star \star}$ & $0.292^{\star \star}$ \\
\hline & (1.96) & $(2.09)$ & $(2.02)$ & $(2.14)$ & $(2.27)$ & $(2.31)$ \\
\hline \multirow[t]{2}{*}{ Share_F } & $-0.171^{* *}$ & $-0.166^{* *}$ & $-0.165^{\star *}$ & $-0.169^{* *}$ & $-0.164^{* *}$ & $-0.165^{\star *}$ \\
\hline & $(-2.39)$ & $(-2.23)$ & $(-2.21)$ & $(-2.40)$ & $(-2.23)$ & $(-2.27)$ \\
\hline \multirow[t]{2}{*}{ History } & $0.045^{* * *}$ & $0.045^{\star * *}$ & $0.046^{* * *}$ & $0.047^{* * *}$ & $0.047^{* * *}$ & $0.047^{* * *}$ \\
\hline & (5.37) & $(5.45)$ & $(5.97)$ & $(6.41)$ & $(6.39)$ & $(6.12)$ \\
\hline \multirow[t]{2}{*}{ Method } & 0.024 & 0.023 & 0.024 & 0.028 & 0.026 & 0.026 \\
\hline & $(1.34)$ & $(1.20)$ & $(1.27)$ & (1.59) & $(1.45)$ & $(1.42)$ \\
\hline \multirow[t]{2}{*}{ Advisor } & $-0.043^{* * *}$ & $-0.042^{* * *}$ & $-0.039^{* * *}$ & $-0.042^{\star * *}$ & $-0.041^{\star * *}$ & $-0.041^{\star * *}$ \\
\hline & $(-6.12)$ & $(-5.00)$ & $(-4.55)$ & $(-5.97)$ & $(-4.95)$ & $(-5.57)$ \\
\hline \multirow[t]{2}{*}{ Age_T } & -0.001 & -0.001 & -0.001 & -0.001 & -0.001 & -0.001 \\
\hline & $(-0.67)$ & $(-0.60)$ & $(-0.62)$ & $(-0.59)$ & $(-0.53)$ & $(-0.52)$ \\
\hline \multirow[t]{2}{*}{ FCP } & $-0.073^{* * *}$ & $-0.073^{* * *}$ & $-0.071^{* * *}$ & $-0.071^{\star * *}$ & $-0.071^{\star * *}$ & $-0.072^{\star * *}$ \\
\hline & $(-13.26)$ & $(-12.59)$ & $(-9.93)$ & $(-11.03)$ & $(-10.52)$ & $(-8.05)$ \\
\hline \multirow[t]{2}{*}{ _cons } & 0.422 & 0.429 & 0.433 & 0.399 & 0.406 & 0.406 \\
\hline & (1.57) & $(1.61)$ & $(1.63)$ & $(1.36)$ & (1.39) & $(1.39)$ \\
\hline Industry & yes & yes & yes & yes & yes & yes \\
\hline Year & yes & yes & yes & yes & yes & yes \\
\hline $\mathrm{r} 2$ & 0.171 & 0.173 & 0.175 & 0.174 & 0.175 & 0.175 \\
\hline $\mathrm{F}$ & 48.710 & 55.318 & 68.705 & 47.992 & 53.896 & 93.011 \\
\hline $\mathrm{N}$ & 419.000 & 419.000 & 419.000 & 419.000 & 419.000 & 419.000 \\
\hline
\end{tabular}

Note: ${ }^{*},{ }^{* *},{ }^{* *}$ respectively indicate significant correlation at $10 \%, 5 \%, 1 \%$ level. $\mathrm{T}$ values in brackets. 
sition premium. Model (1) first adds control variables as the benchmark model, regression results in model (2) with executives' overconfidence as explanatory variables show that executives' overconfidence coefficient is 0.017 , significant at the 5\% level, by controlling the variables that may affect the acquisition premium, which suggests executives' overconfidence significantly enhance the size of acquisition premium. The hypothesis 1 is supported. In model (1) and (2), the coefficient of political connection is negative, but not significant, indicating that political connection do not directly have a significant negative impact on the premium. The model (3) reports the regression results after adding the variables of political connection. The results show that the coefficient of overconfidence and political correlation is -0.034 , which is also significant at $5 \%$ level, indicating that the political connection will weaken the influence of executives' overconfidence on the acquisition premium. The hypothesis $2 \mathrm{a}$ is supported. The models (4), (5), (6) show the regression results of the relationship between executives' overconfidence, political connection level and acquisition premium. The model (6) shows that the coefficient of overconfidence and political connection level is 0.02 , and not significant, indicating that the higher the level of political connection is, the less likely it is to weaken the impact of executives overconfidence on the acquisition premium. So the hypothesis $2 \mathrm{~b}$ is not supported. This may be because the higher the level of political connection, the higher the reputation of the firm, will help to enhance investor confidence in the decision-making of the company, which will bring more financing to the company. Instead, overconfident executives may pay higher premium for the acquisitions.

\subsection{Robustness Test}

To test the reliability of the above results, we use a composite index of executives' personal characteristics as a measure of executives' overconfidence to carry out the robustness test. In the same way, all the acquisitions events of A-share listed companies in 2007 and 2014 were selected as the initial sample. After eliminating the sample that did not meet the relevant requirements, the final sample value was 1100. Table 3 shows the regression results of OC2 as a measure of executives' overconfidence. The Model (2) shows that the executives' overconfidence coefficient is 0.013 and is significant at the $5 \%$ level. The hypothesis 1 is supported. The Model (3) shows that the coefficient of overconfidence and political connection is -0.065 and is significant at the $5 \%$ level. The hypothesis $2 \mathrm{a}$ is supported. The Model (6) suggests that the regression coefficient for executives' overconfidence and political connection level is negative but not significant, indicating that hypothesis $2 \mathrm{~b}$ is not supported. The results of robustness test are similar to those in Table 2, which shows that the conclusion of this study has good stability.

\section{Conclusions}

Acquisition events of all A-share listed companies in 2007-2014 taken as the sample, we empirically test the relationship between executives' overconfidence 
Table 3. Relationship between overconfidence and acquisition premium test (OC2).

\begin{tabular}{|c|c|c|c|c|c|c|}
\hline variables & Model(1) & Model(2) & Model(3) & Model(4) & Model(5) & Model(6) \\
\hline \multirow[t]{2}{*}{ OC2 } & & $0.013^{* *}$ & $0.012^{* * *}$ & & $0.011^{*}$ & $0.009^{* *}$ \\
\hline & & $(2.57)$ & $(2.58)$ & & $(1.82)$ & $(2.07)$ \\
\hline \multirow[t]{2}{*}{$\mathrm{PC} \times \mathrm{OC} 2$} & & & $-0.065^{\star *}$ & & & \\
\hline & & & $(-2.09)$ & & & \\
\hline \multirow[t]{2}{*}{ PCL $\times \mathrm{OC} 2$} & & & & & & -0.003 \\
\hline & & & & & & $(-0.70)$ \\
\hline \multirow[t]{2}{*}{ PC } & 0.007 & 0.006 & 0.006 & & & \\
\hline & $(0.32)$ & $(0.29)$ & $(0.29)$ & & & \\
\hline \multirow[t]{2}{*}{ PCL } & & & & $-0.004^{\star}$ & -0.004 & $-0.004^{\star}$ \\
\hline & & & & $(-1.87)$ & $(-1.60)$ & $(-1.67)$ \\
\hline \multirow[t]{2}{*}{ Size } & $-0.014^{* * *}$ & $-0.014^{\star * *}$ & $-0.013^{\star * *}$ & $-0.013^{* * *}$ & $-0.013^{* * *}$ & $-0.013^{* * *}$ \\
\hline & $(-3.76)$ & $(-3.82)$ & $(-3.67)$ & $(-3.54)$ & $(-3.52)$ & $(-3.52)$ \\
\hline \multirow[t]{2}{*}{ Age_C } & $-0.022^{* * *}$ & $-0.022^{\star * \star}$ & $-0.023^{\star * *}$ & $-0.024^{* * *}$ & $-0.024^{* * *}$ & $-0.024^{* * *}$ \\
\hline & $(-3.48)$ & $(-3.44)$ & $(-3.45)$ & $(-4.86)$ & $(-4.74)$ & $(-4.76)$ \\
\hline \multirow[t]{2}{*}{ Cash_F } & $0.000^{* *}$ & $0.000^{* *}$ & $0.000^{\star * *}$ & 0.000 & 0.000 & 0.000 \\
\hline & $(2.30)$ & $(2.42)$ & $(2.63)$ & $(1.32)$ & $(1.30)$ & $(1.32)$ \\
\hline \multirow[t]{2}{*}{ ROA } & $0.123^{* *}$ & $0.136^{\star *}$ & $0.129^{* *}$ & $0.148^{* * *}$ & $0.157^{\star * *}$ & $0.155^{\star * *}$ \\
\hline & $(2.20)$ & $(2.41)$ & $(2.41)$ & $(2.65)$ & $(2.74)$ & $(2.85)$ \\
\hline \multirow[t]{2}{*}{ Ind_ratio } & 0.023 & 0.020 & 0.011 & 0.030 & 0.027 & 0.025 \\
\hline & $(0.42)$ & $(0.36)$ & $(0.19)$ & $(0.51)$ & $(0.46)$ & $(0.41)$ \\
\hline \multirow[t]{2}{*}{ Share_F } & 0.008 & 0.008 & 0.007 & 0.010 & 0.009 & 0.009 \\
\hline & $(0.15)$ & $(0.15)$ & $(0.13)$ & $(0.18)$ & $(0.17)$ & $(0.17)$ \\
\hline \multirow[t]{2}{*}{ History } & $0.027^{* * *}$ & $0.026^{* * *}$ & $0.025^{* *}$ & $0.028^{\star * *}$ & $0.028^{* * *}$ & $0.028^{* * *}$ \\
\hline & (2.59) & $(2.60)$ & $(2.58)$ & (2.59) & $(2.60)$ & $(2.62)$ \\
\hline \multirow[t]{2}{*}{ Method } & $0.018^{*}$ & $0.017^{\star}$ & 0.014 & 0.018 & 0.017 & 0.017 \\
\hline & (1.78) & $(1.66)$ & (1.46) & $(1.60)$ & $(1.54)$ & $(1.52)$ \\
\hline \multirow[t]{2}{*}{ Advisor } & $-0.054^{* * *}$ & $-0.054^{* * *}$ & $-0.056^{\star * *}$ & $-0.054^{* * *}$ & $-0.055^{\star * *}$ & $-0.055^{\star * *}$ \\
\hline & $(-3.18)$ & $(-3.09)$ & $(-3.11)$ & $(-2.92)$ & $(-2.87)$ & $(-2.85)$ \\
\hline \multirow[t]{2}{*}{ Age_T } & 0.002 & 0.002 & 0.002 & 0.002 & 0.002 & 0.002 \\
\hline & (1.19) & $(1.31)$ & $(1.21)$ & (1.18) & $(1.22)$ & $(1.21)$ \\
\hline \multirow[t]{2}{*}{ FCP } & $-0.069^{* * *}$ & $-0.071^{\star * *}$ & $-0.073^{* * *}$ & $-0.063^{* * *}$ & $-0.065^{\star * *}$ & $-0.066^{* * *}$ \\
\hline & $(-7.34)$ & $(-7.16)$ & $(-6.99)$ & $(-7.50)$ & $(-7.22)$ & $(-7.22)$ \\
\hline \multirow[t]{2}{*}{ _cons } & $0.289^{* * *}$ & $0.263^{* * *}$ & $0.288^{\star * *}$ & $0.273^{\star * *}$ & $0.254^{* * *}$ & $0.256^{\star * *}$ \\
\hline & $(4.86)$ & $(4.68)$ & $(4.70)$ & $(4.34)$ & $(4.12)$ & $(4.13)$ \\
\hline Industry & yes & yes & yes & yes & yes & yes \\
\hline Year & yes & yes & yes & yes & yes & yes \\
\hline $\mathrm{r} 2$ & 0.112 & 0.113 & 0.117 & 0.114 & 0.114 & 0.115 \\
\hline F & 18.918 & 19.615 & 14.743 & 15.841 & 16.926 & 15.748 \\
\hline $\mathrm{N}$ & 1100.000 & 1100.000 & 1100.000 & 1100.000 & 1100.000 & 1100.000 \\
\hline
\end{tabular}

Note: ${ }^{*},{ }^{* *},{ }^{* *}$ respectively indicate significant correlation at $10 \%, 5 \%, 1 \%$ level. $\mathrm{T}$ values in brackets. 
and acquisition premium. The study finds that Chinese enterprises in the context of the transition economy, as the main body of the new round of acquisitions, initiate acquisition premium behavior that are highly associated with executives' overconfidence, which is consistent with the foreign research conclusions. Further, breaking through the existing research based on the perspective of capital and board of directors, we combine executive's irrationality with political connection to study the mechanisms of weakening or strengthening the influence of overconfidence on the acquisition premium from the perspective of political connection. Different from the previous studies, this paper combines the two mechanisms of political connection-weakening the control of illusion and information provision, and draws a conclusion different from the existing research. It shows the political connection will weaken the influence of executives' overconfidence on the acquisitions premium; however, political connection level is not necessarily an important safeguard against weakening the executives' overconfidence.

The political connection does not have a direct and significant impact on the corporate buy-out premium, but rather by weakening the manager's illusion, reducing the manager's opportunistic behavior, providing more comprehensive and reliable information, so that making the overconfident manager finally make more rational and reasonable acquisition decision. This reveals a deeplevel mechanism about how the political connection affect the enterprise Strategic decision-making and selection, also suggests political connection can serve as an effective governance mechanism to help the enterprises with overconfident executives to make scientific and reasonable investment decisions,. As a result, the enterprises with overconfident executives can make full of the political connection to reduce the non-rational investment activities, and finally help enterprises to realize healthy development.

But at the same time, it is necessary to examine the role of political connection. The higher level of political connection does not necessarily mean more easily weaken negative influences of executives' overconfidence. It shows that the political connection level is not the higher the better. Excessive attention to the construction of the political connection level will lead to excessive government intervention and control in the corporate decision-making to restrict managerial discretion to a greater extent and will lead to excessive dependence on political connection while ignoring the construction of enterprises' internal capacity (e.g. innovation. internal governance). Therefore, in the current background of China's transition economy, the establishment of a benign political connection is extremely necessary. Chinese entrepreneurs should pay more attention to innovation, focus on improving their "hard power", rather than engage in "relations". At the same time, the government should pay more attention to serving and building a platform to help enterprises to grow faster and stronger.

\section{References}

[1] Roll, R. (1986) The Hubris Hypothesis of Corporate Takeover. Journal of Business, 59, 197-216. https://doi.org/10.1086/296325 
[2] Wang, X., Zhang, M. and Yu, F. (2008) CEO Overconfidence and Distortion of Firms' Investments: Some Empirical Evidence from China. Nankai Management Review, 11, 77-83.

[3] Malmendier, U. and Tate, G. (2003) Who Makes Acquisitions? CEO Overconfidence and the Market's Reaction. Journal of Financial Economics, 89, 20-43. https://doi.org/10.1016/j.jfineco.2007.07.002

[4] Song, S. and Dai, S. (2015) Managerial Overconfidence, M \& A Type and M \& A Performance. Macroeconomics, 5, 139-149.

[5] Hayward, M.L.A. and Hambrick, D.C. (1997) Explaining the Premiums Paid for Large Acquisitions: Evidence of CEO Hubris. Administrative Science Quarterly, 42, 103-127. https://doi.org/10.2307/2393810

[6] Zhu, L. and Yu, W. (2015) Board Governance, CEO Overconfidence and Enterprise Merger Policy Decision. Journal of Shandong University of Finance, 1, 107-115.

[7] Malmendier, U. and Tate, G. (2006) CEO Overconfidence and Corporate Investment. Strategic Direction, 60, 2661-2700.

[8] Di, A. and Zhang, X. (2012) On the Relationship among Managerial Overconfidence, Acquisition Performance. Modern Finance and Economics-Journal, 10, 102 114.

[9] Zeng, P. and Song, T. (2012) A Study on the Relationship of the Political Connections and Organizational. Chinese Journal of Management, 3, 364-370.

[10] Yu, M. and Pan, H. (2008) Political Relevance, Institutional Environment and Private Enterprise Bank Loans. Management World, 8, 9-18.

[11] Pan, H. and Yu, M. (2011) Support Hand, Plunder Hand and Off-Site Mergers and Acquisitions. Economic Research Journal, 9, 108-120.

[12] Yi, J., Zhang, X. and Wang, H. (2015) Enterprise Heterogeneity, Executive Overconfidence and Enterprise Innovation Performance. Nankai Business Review, 18, 101-112.

[13] Camerer, C. and Dan, L. (1996) Overconfidence and Excess Entry: An Experimental Approach. American Economic Review, 89, 306-318.

[14] Fang, J. (2008) The Government Intervention, the Nature of Ownership and Enterprises' Mergers \& Acquisitions. Management World, 9, 118-123.

[15] Zhou, J. and Xue, Y. (2011) The Effect of Venture Capital on the Performance of IPO Companies. Nankai Business Review, 14, 65-74.

[16] Chen, S. and Lu, C. (2013) Enterprise Connectivity and M \& A Premium Decision-An Empirical Study Based on Inter-Organizational Imitation Theory. Management World, 5, 144-156.

[17] Jiang, Y. (2014) Dual Political Connection and M \& A Premium-An Empirical Study Based on the M \& A Event of A-Share Listed Companies from 2003 to 2012. Macroeconomics, 2, 63-71.

[18] Yu, M., Li, W. and Pan, H. (2013) Manager Overconfidence and Corporate Risk Commitment. Finance Research, 1, 149-163.

[19] Doukas, J.A. and Petmezas, D. (2007) Acquisitions, Overconfident Managers and Self-Attribution Bias. European Financial Management, 13, 531-577. https://doi.org/10.1111/j.1468-036X.2007.00371.X

[20] Pan, H., Xia, X. and Yu, M. (2008) Government Intervention, Political Relevance and Local State-Owned Enterprise M\&A. Economic Research, 4, 41-52.

[21] Tang, S. and Sun, Z. (2014) Political Relevance, Executive Salary and Corporate Future Performance. Management World, 5, 93-105. 


\section{Appendix 1}

A-share listed companies (249 companies, 419 observed values).

\begin{tabular}{|c|c|c|}
\hline No. & Company name & $\begin{array}{c}\text { Aqusition } \\
\text { events }\end{array}$ \\
\hline 1 & COFCO Property (Group) Co., Ltd. & 6 \\
\hline 2 & Shenzhen Centralcon Investment Holding Co., Ltd. & 2 \\
\hline 3 & Zoomlion Heavy Industry Science and Technology Co., Ltd. & 1 \\
\hline 4 & Wuhan Department Store Group Co., Ltd. & 1 \\
\hline 5 & Kunming Sinobright (Group) Co., Ltd. & 4 \\
\hline 6 & Jiangsu Youli Investment Holding Co., Ltd & 1 \\
\hline 7 & Chengdu Xingrong Environment Co., Ltd. & 9 \\
\hline 8 & Xi'An Tourism Co., Ltd. & 1 \\
\hline 9 & Kinghand Industrial Investment Co., Ltd. & 1 \\
\hline 10 & Tianjin TEDA Co., Ltd. & 3 \\
\hline 11 & Shandong Jinling Mining Co., Ltd. & 2 \\
\hline 12 & Shantui Construction Machinery Co., Ltd. & 1 \\
\hline 13 & Shanxi Taigang Stainless Steel Co., Ltd. & 3 \\
\hline 14 & Anhui Ankai Automobile Co., Ltd. & 1 \\
\hline 15 & Zoje Resources Investment Co., Ltd. & 1 \\
\hline 16 & Beijing SL Pharmaceutical Co., Ltd. & 2 \\
\hline 17 & Dehua TB New Decoration Material Co., Ltd. & 1 \\
\hline 18 & Ningbo Huaxiang Electronic Co., Ltd. & 1 \\
\hline 19 & Zhejiang Jingxing Paper Joint Stock Co., Ltd. & 2 \\
\hline 20 & Zhejiang Wanfeng Auto Wheel Co., Ltd. & 1 \\
\hline 21 & Xinjiang Zhongtai Chemical Co., Ltd. & 1 \\
\hline 22 & Ningbo Kangqiang Electronics Co., Ltd. & 1 \\
\hline 23 & Shenzhen Sunlord Electronics Co., Ltd. & 1 \\
\hline 24 & Risesun Real Estate Development Co., Ltd. & 1 \\
\hline 25 & Zhejiang Guangsha Co., Ltd. & 9 \\
\hline 26 & China Northern Rare Earth (Group) High-Tech Co., Ltd. & 2 \\
\hline 27 & Shenzhen Heungkong Holding Co., Ltd. & 1 \\
\hline 28 & Xinhu Zhongbao Co., Ltd. & 1 \\
\hline 29 & Hubei Sanxia New Building Materials Co., Ltd. & 1 \\
\hline 30 & Hunan Corun New Energy Co., Ltd. & 1 \\
\hline 31 & Xinjiang Urban Construction(Group)Co., Ltd. & 1 \\
\hline 32 & Eastern Communications Co., Ltd. & 1 \\
\hline 33 & GD Power Development Co., Ltd. & 13 \\
\hline 34 & Xiamen XGMA Machinery Company Limited. & 2 \\
\hline 35 & Shanghai Xinhua Media Co., Ltd. & 1 \\
\hline
\end{tabular}




\section{Continued}

\begin{tabular}{|c|c|c|}
\hline 36 & Shanghai Zhangjiang Hi-Tech Park Development Co., Ltd. & 1 \\
\hline 37 & LANHAI MEDICAL INVESTMENT CO., LTD. & 1 \\
\hline 38 & North Huajin Industries Co., Ltd. & 1 \\
\hline 39 & Lvjing Holding Co., Ltd. & 1 \\
\hline 40 & Hainan Haiyao Co., Ltd. & 2 \\
\hline 41 & Northeast Pharmaceutical Group Co., Ltd. & 1 \\
\hline 42 & Transfar Zhilian Co., Ltd. & 1 \\
\hline 43 & Cefc Anhui International Holding Co., Ltd. & 1 \\
\hline 44 & Shenzhen Coship Electronics Co., Ltd. & 3 \\
\hline 45 & Dymatic Chemicals, Inc. & 1 \\
\hline 46 & Sinoma Science \& Technology Co., Ltd. & 1 \\
\hline 47 & Cangzhou Mingzhu Plastic Co., Ltd. & 1 \\
\hline 48 & Jilin Zixin Pharmaceutical Industrial Co., Ltd. & 1 \\
\hline 49 & Tianjin Zhonghuan Semiconductor Co., Ltd. & 4 \\
\hline 50 & Shenzhen Hifuture Electric Co., Ltd. & 2 \\
\hline 51 & Shaanxi Provincial Natural Gas Co., Ltd. & 1 \\
\hline 52 & Hubei Xingfa Chemicals Group Co., Ltd. & 1 \\
\hline 53 & Yanzhou Coal Mining Company Limited & 3 \\
\hline 54 & Xinjiang Tianrun Dairy Co., Ltd. & 1 \\
\hline 55 & North Navigation Control Technology Co., Ltd. & 1 \\
\hline 56 & Hebei Hengshui Laobaigan Liquor Co., Ltd. & 2 \\
\hline 57 & Shenzhen Textile (Holdings) Co., Ltd. & 2 \\
\hline 58 & Guizhou Tyre Co., Ltd. & 1 \\
\hline 59 & Maoming Petro-Chemical Shihua Co., Ltd. & 3 \\
\hline 60 & Visual China Group Co., Ltd. & 1 \\
\hline 61 & PKU HealthCare Corp., Ltd. & 4 \\
\hline 62 & Henan Tongli Cement Co., Ltd. & 1 \\
\hline 63 & United Science \& Technology Co., Ltd. & 1 \\
\hline 64 & Huadong Medicine Co., Ltd. & 1 \\
\hline 65 & Guodian Changyuan Electric Power Co., Ltd. & 1 \\
\hline 66 & Huagong Tech Company Limited & 2 \\
\hline 67 & Chengzhi Co., Ltd. & 1 \\
\hline 68 & Chongqing Zongshen Power Machinery Co., Ltd. & 2 \\
\hline 69 & Zhejiang Kan Specialities Material Co., Ltd. & 1 \\
\hline 70 & Luoyang Bearing Science \& Technology Co., Ltd. & 1 \\
\hline 71 & Weihai Guangtai Airport Equipment Co., Limited & 6 \\
\hline 72 & Tianma Bearing Group Co., Ltd. & 1 \\
\hline 73 & Guangzhou Grandbuy Co., Ltd. & 1 \\
\hline
\end{tabular}




\section{Continued}

\begin{tabular}{|c|c|c|}
\hline 74 & Hefei Urban Construction Development Co., Ltd. & 1 \\
\hline 75 & Zhejiang Great Southeast Co., Ltd. & 2 \\
\hline 76 & Huaneng Power International, Inc. & 1 \\
\hline 77 & Beiqi Foton Motor Co., Ltd. & 1 \\
\hline 78 & Anhui Jianghuai Automobile Group Corp., Ltd. & 5 \\
\hline 79 & Ningbo Fubang Jingye Group Co., Ltd. & 1 \\
\hline 80 & SDIC Power Holdings Co., Ltd. & 1 \\
\hline 81 & Anhui Fengyuan Pharmaceutical Co., Ltd. & 1 \\
\hline 82 & Shenyang Machine Tool Co., Ltd. & 1 \\
\hline 83 & Changsha Tongcheng Holdings Co., Ltd. & 1 \\
\hline 84 & Zhang Jia Jie Tourism Group Co., Ltd. & 3 \\
\hline 85 & Guangdong Highsun Group Co., Ltd. & 5 \\
\hline 86 & Harbin Electric Corporation Jiamusi Electric Machine Co., Ltd. & 1 \\
\hline 87 & Ningxia Zhongyin Cashmere Co., Ltd. & 1 \\
\hline 88 & Zhejiang Weixing Industrial Development Co., Ltd. & 1 \\
\hline 89 & Zhejiang Jinggong Science \& Technology Co., Ltd. & 1 \\
\hline 90 & Zhejiang Dun'An Artificial Environment Co., Ltd. & 1 \\
\hline 91 & Guizhou Space Appliance Co., Ltd. & 3 \\
\hline 92 & Huafu Top Dyed Melange Yarn Co., Ltd. & 2 \\
\hline 93 & ZHEJIANG SANHUA INTELLIGENT CONTROLS CO., LTD. & 1 \\
\hline 94 & China CAMC Engineering Co., Ltd. & 1 \\
\hline 95 & Mesnac Co., Ltd. & 1 \\
\hline 96 & Suzhou Gold Mantis Construction Decoration Co., Ltd. & 1 \\
\hline 97 & China Haisum Engineering Co., Ltd. & 1 \\
\hline 98 & Yunda Holding Co., Ltd. & 2 \\
\hline 99 & Zhejiang Yinlun Machinery Co., Ltd. & 1 \\
\hline 100 & Huolinhe Opencut Coal Industry Corporation Limited of Inner Mongolia & 1 \\
\hline 101 & Shandong Humon Smelting Co., Ltd. & 1 \\
\hline 102 & Hunan Friendship\&Apollo Commercial Co., Ltd. & 1 \\
\hline 103 & Zhejiang Asia-Pacific Mechanical\& Electronic Co., Ltd. & 1 \\
\hline 104 & Guangdong Jingyi Metal Co., Ltd. & 3 \\
\hline 105 & Jiangsu Yanghe Brewery Joint-Stock Co., Ltd. & 1 \\
\hline 106 & S.F. Holding Co., Ltd. & 1 \\
\hline 107 & Xiamen Academy of Building Research Group Co., Ltd. & 1 \\
\hline 108 & Zhejiang Jiaxin Silk Corp., Ltd. & 1 \\
\hline 109 & Zibo Qixiang Tengda Chemical Co., Ltd. & 1 \\
\hline 110 & Shenzhen DAS Intellitech Co., Ltd. & 1 \\
\hline 111 & Hangzhou Hangyang Co., Ltd. & 1 \\
\hline
\end{tabular}




\section{Continued}

\begin{tabular}{|c|c|c|}
\hline 112 & Zhejiang Runtu Co., Ltd. & 1 \\
\hline 113 & Huayi Brothers Media Corporation & 1 \\
\hline 114 & Jiangsu Wuzhong Industrial Co., Ltd. & 2 \\
\hline 115 & COSCO SHIPPING Specialized Carriers Co., Ltd. & 1 \\
\hline 116 & Zhongjin Gold Corp., Ltd. & 2 \\
\hline 117 & Xiamen Tungsten Co., Ltd. & 1 \\
\hline 118 & Wuchan Zhongda Group Co., Ltd. & 1 \\
\hline 119 & Shandong Binzhou Bohai Piston Co., Ltd. & 2 \\
\hline 120 & Nanjing Red Sun Co., Ltd. & 1 \\
\hline 121 & Zhejiang Zhenyuan Share Co., Ltd. & 1 \\
\hline 122 & Huapont Life Sciences Co., Ltd. & 3 \\
\hline 123 & Jiangxi Black Cat Carbon Black Co., Ltd. & 1 \\
\hline 124 & Anhui Annada Titanium Industry Co., Ltd. & 2 \\
\hline 125 & Shenzhen Topway Video Communication Co., Ltd. & 1 \\
\hline 126 & Xinjiang Beixin Road and Bridge Group Co., Ltd. & 2 \\
\hline 127 & Anhui Wantong Technology Co., Ltd. & 1 \\
\hline 128 & Shandong Longji Machinery Co., Ltd. & 5 \\
\hline 129 & NAURA Technology Group Co., Ltd. & 1 \\
\hline 130 & Suzhou Dongshan Precision Manufacturing Co., Ltd. & 2 \\
\hline 131 & Yibin Tianyuan Group Co., Ltd. & 1 \\
\hline 132 & Guangdong Advertising Group Co., Ltd. & 1 \\
\hline 133 & Navinfo Co., Ltd. & 1 \\
\hline 134 & Guizhou Bailing Group Pharmaceutical Co., Ltd. & 1 \\
\hline 135 & Kaiser (China) Culture Co., Ltd. & 1 \\
\hline 136 & Guangdong Taiantang Pharmaceutical Co., Ltd. & 1 \\
\hline 137 & Hangzhou Great Star Industrial Co., Ltd. & 2 \\
\hline 138 & Suzhou Tianma Specialty Chemicals Co., Ltd. & 1 \\
\hline 139 & Guangzhou Haige Communications Group Incorporated Company & 1 \\
\hline 140 & Shanghai STEP Electric Corporation & 1 \\
\hline 141 & Anhui Huilong Agricultural Means of Production. Co., Ltd. & 1 \\
\hline 142 & Himile Mechanical Science and Technology (Shandong) Co., Ltd. & 1 \\
\hline 143 & Shenzhen Danbond Technology Co., Ltd. & 1 \\
\hline 144 & Sichuan Western Resources Holding Co., Ltd. & 1 \\
\hline 145 & Zhejiang Juhua Co., Ltd. & 1 \\
\hline 146 & Keda Clean Energy Co., Ltd. & 1 \\
\hline 147 & Huaxin Cement Co., Ltd. & 1 \\
\hline 148 & Sinopec Shandong Taishan Pectroleum Co., Ltd. & 1 \\
\hline 149 & Hunan Development Group Co., Ltd. & 1 \\
\hline
\end{tabular}




\section{Continued}

\begin{tabular}{|c|c|c|}
\hline 150 & Hongda Xingye Co., Ltd. & 2 \\
\hline 151 & Yunnan Tourism Co., Ltd. & 2 \\
\hline 152 & Hongda High-Tech Holding Co., Ltd. & 1 \\
\hline 153 & CNNC Hua Yuan Titanium Dioxide Co., Ltd. & 1 \\
\hline 154 & Jiangxi Special Electric Motor Co., Ltd. & 1 \\
\hline 155 & Jiangsu Yuyue Medical Equipment \& Supply Co., Ltd. & 5 \\
\hline 156 & Goertek Inc. & 1 \\
\hline 157 & Lianhe Chemical Technology Co., Ltd. & 3 \\
\hline 158 & Zhejiang Wanma Co., Ltd. & 3 \\
\hline 159 & Hunan Boyun New Materials Co., Ltd. & 1 \\
\hline 160 & China West Construction Group Co., Ltd. & 4 \\
\hline 161 & Zhejiang JIULI Hi-tech Metals Co., Ltd. & 1 \\
\hline 162 & Nantong Jinghua Pharmaceutical Co., Ltd. & 1 \\
\hline 163 & Sichuan Fulin Transportation Group Co., Ltd. & 1 \\
\hline 164 & Blue Sail Medical Co., Ltd. & 1 \\
\hline 165 & Jiangsu Zhongchao Holding Co., Ltd. & 2 \\
\hline 166 & Sichuan Yahua Industrial Group Co., Ltd. & 3 \\
\hline 167 & Qingdao Hanhe Cable Co., Ltd. & 1 \\
\hline 168 & Tatwah Smartech Co., Ltd. & 1 \\
\hline 169 & Shimge Pump Industry Group Co., Ltd. & 1 \\
\hline 170 & Shenzhen Jinxinnong Technology Co., Ltd. & 1 \\
\hline 171 & Tangrenshen Group Co., Ltd. & 1 \\
\hline 172 & Suofeiya Home Collection Co., Ltd. & 8 \\
\hline 173 & Beijing SPC Environment Protection Tech Co., Ltd. & 1 \\
\hline 174 & Xilong Scientific Co., Ltd. & 1 \\
\hline 175 & JPMF Guangdong Co., Ltd. & 1 \\
\hline 176 & Yonggao Co., Ltd. & 1 \\
\hline 177 & United Electronics Co., Ltd. & 2 \\
\hline 178 & Beyondsoft Corporation & 1 \\
\hline 179 & Zhejiang Yilida Ventilator Co., Ltd. & 1 \\
\hline 180 & Recon Wenyuan Cable Co., Ltd. & 2 \\
\hline 181 & Henan Pinggao Electric Co., Ltd. & 2 \\
\hline 182 & Shanghai Ya Tong Co., Ltd. & 1 \\
\hline 183 & Wasu Media Holding Co., Ltd. & 4 \\
\hline 184 & Yunnan Baiyao Group Co., Ltd. & 1 \\
\hline 185 & China Media Group & 1 \\
\hline 186 & Unisplendour Corporation Limited & 1 \\
\hline 187 & YIFANPHARMACEUTICAL CO., LTD. & 1 \\
\hline
\end{tabular}




\section{Continued}

\begin{tabular}{|c|c|c|}
\hline 188 & Meinian Onehealth Healthcare Holdings Co., Ltd. & 1 \\
\hline 189 & Shenzhen Deren Electronic Co., Ltd. & 2 \\
\hline 190 & Guangdong No.2 Hydropower Engineering Co., Ltd. & 2 \\
\hline 191 & Guoxuan High-Tech Co., Ltd. & 1 \\
\hline 192 & Hunan Nanling Industrial Explosive Materials Co., Ltd. & 1 \\
\hline 193 & San Bian Science \& Technology Co., Ltd. & 1 \\
\hline 194 & Anhui Truchum Advanced Materials and Technology Co., Ltd. & 1 \\
\hline 195 & Youngy Co., Ltd. & 2 \\
\hline 196 & Guangdong Jiaying Pharmaceutical Co., Ltd. & 1 \\
\hline 197 & Shenzhen Noposion Agrochemicals Co., Ltd. & 1 \\
\hline 198 & Sanquan Food Co., Ltd. & 1 \\
\hline 199 & Shanghai Xinpeng Industry Co., Ltd. & 3 \\
\hline 200 & Taiji Computer Corporation Limited & 2 \\
\hline 201 & Guizhou Xinbang Pharmaceutical Co., Ltd. & 1 \\
\hline 202 & Beijing Lier High-Temperature Materials Co., Ltd. & 1 \\
\hline 203 & Shenzhen Glory Medical Co., Ltd. & 1 \\
\hline 204 & Suzhou Thvow Technology Co., Ltd. & 1 \\
\hline 205 & Shandong Longlive Bio-Technology Co., Ltd. & 4 \\
\hline 206 & Roshow Technology Co., Ltd. & 2 \\
\hline 207 & Chengdu Hongqi Chain Co., Ltd. & 2 \\
\hline 208 & Hangzhou Huaxing Chuangye Communication Technology Co., Ltd. & 2 \\
\hline 209 & Jsti Group & 1 \\
\hline 210 & Citychamp Dartong Co., Ltd. & 4 \\
\hline 211 & Grinm Advanced Materials Co., Ltd. & 2 \\
\hline 212 & Jiangsu Sainty Corp., Ltd. & 1 \\
\hline 213 & Chengtun Mining Group Co., Ltd. & 2 \\
\hline 214 & Huadian Energy Company Limited & 2 \\
\hline 215 & Inner Mongolia Yuan Xing Energy Company Limited & 1 \\
\hline 216 & Da An Gene Co., Ltd. of Sun Yat-Sen University & 2 \\
\hline 217 & Unigroup Guoxin Co., Ltd. & 1 \\
\hline 218 & YGSOFT Inc. & 1 \\
\hline 219 & Tecon Biology Co. Ltd. & 4 \\
\hline 220 & China Quanjude(Group) Co., Ltd. & 3 \\
\hline 221 & Zhejiang Founder Motor Co., Ltd. & 1 \\
\hline 222 & Jiangsu Hongda New Material Co., Ltd. & 1 \\
\hline 223 & Hengkang Medical Group Co., Ltd. & 1 \\
\hline 224 & Puyang Refractories Group Co., Ltd. & 1 \\
\hline 225 & Guilin Sanjin Pharmaceutical Co., Ltd. & 1 \\
\hline
\end{tabular}




\section{Continued}

\begin{tabular}{|c|c|c|}
\hline 226 & Alpha Group & 1 \\
\hline 227 & Guangdong Haid Group Co., Limited & 1 \\
\hline 228 & Shandong Delisi Food Co., Ltd. & 1 \\
\hline 229 & Shanghai Zhezhong Group Co., Ltd. & 2 \\
\hline 230 & Zhejiang Yasha Decoration Co., Ltd. & 3 \\
\hline 231 & Shandong New Beiyang Information Technology Co., Ltd. & 1 \\
\hline 232 & Shenzhen Sunyes Electronic Manufacturing Holding Co., Ltd. & 1 \\
\hline 233 & Shenzhen Hepalink Pharmaceutical Co., Ltd. & 1 \\
\hline 234 & ZYNP Corporation & 2 \\
\hline 235 & Jiangsu Yinhe Electronics Co., Ltd. & 1 \\
\hline 236 & Guangdong Vanward New Electric Co., Ltd. & 1 \\
\hline 237 & Brother Enterprises Holding Co., Ltd. & 2 \\
\hline 238 & XinZhi Motor Co., Ltd. & 1 \\
\hline 239 & Guangdong Delian Group Co., Ltd. & 1 \\
\hline 240 & Dongjiang Environmental Company Limited & 6 \\
\hline 241 & Bestway Marine \& Energy Technology Co., Ltd. & 1 \\
\hline 242 & HONZ PHARMACEUTICAL CO., LTD. & 1 \\
\hline 243 & Shenzhen Tatfook Technology Co., Ltd. & 2 \\
\hline 244 & Walvax Biotechnology Co., Ltd. & 1 \\
\hline 245 & ShandongJincheng Pharmaceutical Group Co., Ltd. & 1 \\
\hline 246 & Wenzhou Hongfeng Electrical Alloy Co., Ltd. & 3 \\
\hline 247 & NBTM New Materials Group Co., Ltd. & 4 \\
\hline 248 & Shandong Tyan Home Co., Ltd. & 3 \\
\hline \multirow[t]{2}{*}{249} & G Oriental Pearl & 1 \\
\hline & Total & 419 \\
\hline
\end{tabular}

Submit or recommend next manuscript to SCIRP and we will provide best service for you:

Accepting pre-submission inquiries through Email, Facebook, LinkedIn, Twitter, etc. A wide selection of journals (inclusive of 9 subjects, more than 200 journals)

Providing 24-hour high-quality service

User-friendly online submission system

Fair and swift peer-review system

Efficient typesetting and proofreading procedure

Display of the result of downloads and visits, as well as the number of cited articles

Maximum dissemination of your research work

Submit your manuscript at: http://papersubmission.scirp.org/

Or contact jssm@scirp.org 